\title{
Analysis and Countermeasures Studyof Current Risks in China's Electronics Industry
}

\author{
Tan Hui ${ }^{1}$ and Xie Shufen ${ }^{2}$ \\ (Jiangxi applied engineering vocational college. jiangxi pingxiang 337000 )
}

Keywords: Current Risks Electronics Industry

\begin{abstract}
In corporate business activities, the identification and control of risks by enterprises has become an important task for corporate management activities. This is also a long-term task for companies. For enterprise managers, it is necessary to invest in the company's own operating conditions on a long-term basis, and maintain close attention to the risks the company faces so that it can be done in the shortest possible time in the event of a crisis caused by risks. Correct risk control decisions are made, and corresponding measures and strategies are proposed for different risk assessment types to avoid the recurrence or extension of financial crisis. This paper studies the risk factors and characteristics that enterprises face, and proposes corresponding control measures for each type of risk that companies face.
\end{abstract}

\section{Analysis of Current Risks in China's Electronics Industry}

Overall Status of Risks in China's Electronics Industry

In 2017, the overall operating revenue of the electronics industry in China has a trend of easing compared to the previous quarters. The total revenue for the three quarters of the year was 190.393 billion yuan, up 30.4\% year-on-year and 8.6\% month-on-month, which was weaker than that in last year. Gross margin maintained a relatively stable pattern, and operating margin was relatively high. The major electronics industry companies still have a large profitable space. The profitability of the entire electronics industry is also showing an expanding trend. This also means that the competition between enterprises in the electronics industry in China will also face an expansion. The risk arising from the direction of the market caused by the continuous rise of the entire market will be a major problem that all electronic industry companies must face in the course of their operations.

Development Trend of Risks in China's Electronics Industry

The Global Structure of the Electronics Industry Faces Adjustment

Although the developed countries still control the value of major industries in the electronics industry, China's electronics industry companies have gradually joined the industry's industrial value chain system in recent years. Therefore, this will be a signal that China's electronics industry is facing unprecedented challenges, and it is also an opportunity for China's electronics industry to open up new areas of development. This is followed by the inevitable risks in the challenge.

National Strategies Promote the Development of High-tech Industries

The electronics industry has increasingly become one of the key factors for China's achievement of its goals as a power. National policy guidance clearly points out that the acceleration of the change trend in the development of high-tech industries in the electronics industry. In the reform of policy guidance, it also means that the state supports the high-tech industry, and the risks also contain opportunities. Under such circumstances, enterprises in the electronics industry in China must grasp the latest trends in industrial development, adopt the latest strategy, expand new markets, and accelerate technological upgrading in order to broaden and strengthen their own competitiveness. Under such a general trend, the risks from all sides will follow.

\section{An Empirical Analysis of Financial Data and Risk Definition Values of China's Listed Companies in the Electronic Industry}

This paper selects 13 listed companies in China's electronics industry as an empirical analysis sample. The sample data is taken from the 2017 annual report data of sample listed companies. All 
the data below are from the website of Juchao Information Network and Shanghai Stock Exchange. In order to ensure the comparability and accuracy of the data so as to facilitate better comparative analysis, the following two aspects are taken into consideration in the sample selection process:

First, do not select ST and PT companies. This is mainly because both ST and PT companies are companies that have experienced abnormal changes in their financial conditions in the past two or three years. If such companies are included in the sample, it is very likely that they will lead to conclusions. It is difficult to be convincing.

Second, Considering that the performance of newly-listed companies tends to change to a certain degree for aesthetic reasons, some abnormal data fluctuations may occur. Therefore, in the selection process, this paper will exclude companies listed after 2014.

Proposition of Related Factors

Related Factor One: the liquidity of corporate capital is related to the degree of corporate risk According to the degree of liquidity of the company's capital, it collects the working capital in the sample company's financial report, that is, current assets and current liabilities, and calculates the proportion of the working capital in the total assets of the company.

Related Factor Two: a company's accumulated profits and the length of the business period are related to corporate risk

By collecting the undistributed profits and surplus reserves of the sample companies and calculating the retained earnings of the sample companies, the ratio between the retained earnings of the enterprise and the total assets of the enterprise can roughly reflect the degree of profit accumulation of the enterprise and the operating years of the enterprise.

Related Factor Three: the production capacity of corporate assets is related to corporate risk By collecting the total annual profits of the sample companies and their financial costs, the EBITDA is calculated and the sample company's EBITDA is used as a measure of the utilization of all its equity.

Related Factor Four: the basic financial structure of an enterprise is related to corporate risk By collecting the total value of tradable shares and non-tradable shares of the sample companies, the market capitalization of the company's equity is calculated. By comparing the market capitalization of the company's equity with the total liabilities of the company, the sample company's asset composition is analyzed.

Related Factor Five: a company's sales ability is related to corporate risk

Through the ratio between the main business income and the total assets of the company, the company's sales ability is reflected.

Sample Analysis Statistics

By synthesizing the above five risk-related factors, Table 1 is drawn in this paper to facilitate the statistical analysis of the selected 13 sample companies. 
Table 1 Numerical Synthesis of Risk Variables for Sample Companies in the Electronic Industry in 2017

\begin{tabular}{|c|c|c|c|c|c|c|}
\hline $\begin{array}{l}\text { Comp } \\
\text { any } \\
\text { code }\end{array}$ & Company name & $\begin{array}{l}\text { Value X1 } \\
\text { (working } \\
\text { capital/total } \\
\text { assets) }\end{array}$ & $\begin{array}{l}\text { Value } \quad \text { X2 } \\
\text { (retained } \\
\text { earnings / } \\
\text { total assets) }\end{array}$ & $\begin{array}{l}\text { Value X3 } \\
\text { (EBIT/Gros } \\
\text { s Assets) }\end{array}$ & $\begin{array}{l}\text { Value X4 } \\
\text { (capital market } \\
\text { value/total } \\
\text { book value of } \\
\text { liabilities) }\end{array}$ & $\begin{array}{l}\text { Value } \\
\text { X5 } \\
\text { (Sales } \\
\text { Revenue } \\
\text { /Total } \\
\text { Assets) }\end{array}$ \\
\hline $\begin{array}{l}00081 \\
0\end{array}$ & Skyworth Digital & 0.25 & 0.185 & 0.02 & 0.57 & 0.95 \\
\hline $\begin{array}{l}00082 \\
3\end{array}$ & Goworld & 0.30 & 0.213 & 0.04 & 2.11 & 0.49 \\
\hline $\begin{array}{l}00093 \\
8\end{array}$ & $\begin{array}{l}\text { Unisplendour } \\
\text { Corporation }\end{array}$ & 0.20 & 0.060 & 0.05 & 2.12 & 0.81 \\
\hline $\begin{array}{l}00203 \\
6\end{array}$ & $\begin{array}{l}\text { Lianchuang } \\
\text { Electronics }\end{array}$ & 0.01 & 0.152 & 0.04 & 0.70 & 0.81 \\
\hline $\begin{array}{l}00203 \\
2\end{array}$ & Supor & 0.41 & 0.473 & 0.17 & 1.64 & 1.76 \\
\hline $\begin{array}{l}00204 \\
5\end{array}$ & $\begin{array}{l}\text { Guoguang } \\
\text { Electric }\end{array}$ & 0.09 & 0.145 & 0.04 & 0.59 & 0.89 \\
\hline $\begin{array}{l}00205 \\
5\end{array}$ & $\begin{array}{l}\text { Deren } \\
\text { Electronics }\end{array}$ & 0.10 & 0.087 & 0.01 & 0.39 & 0.39 \\
\hline $\begin{array}{l}00205 \\
0\end{array}$ & $\begin{array}{l}\text { Sanhua } \\
\text { Intelligent } \\
\text { Control } \\
\end{array}$ & 0.44 & 0.332 & 0.10 & 2.11 & 0.58 \\
\hline $\begin{array}{l}00211 \\
9\end{array}$ & $\begin{array}{l}\text { Kang Qiang } \\
\text { Electronics }\end{array}$ & 0.05 & 0.173 & 0.05 & 0.93 & 0.79 \\
\hline $\begin{array}{l}00219 \\
9\end{array}$ & $\begin{array}{l}\text { Dongjing } \\
\text { Electronics }\end{array}$ & 0.19 & -0.511 & -0.01 & 3.10 & 0.21 \\
\hline $\begin{array}{l}00228 \\
9\end{array}$ & $\begin{array}{l}\text { Yushun } \\
\text { Electronics }\end{array}$ & 0.12 & -2.064 & -0.18 & 1.31 & 0.75 \\
\hline $\begin{array}{l}00233 \\
9\end{array}$ & $\begin{array}{l}\text { Integrated } \\
\text { Electronic } \\
\text { Systems Lab }\end{array}$ & 0.45 & 0.209 & 0.03 & 1.10 & 0.44 \\
\hline $\begin{array}{l}00245 \\
1\end{array}$ & Morn Electric & -0.15 & 0.089 & 0.05 & 0.72 & 0.49 \\
\hline
\end{tabular}

Multivariate Linear Model Analysis

The multivariate linear model is as follows:

$\mathrm{Z}=1.2 \mathrm{X}_{1}+1.4 \mathrm{X}_{2}+3.3 \mathrm{X}_{3}+0.6 \mathrm{X}_{4}+0.999 \mathrm{X}_{5}$

The $\mathrm{Z}$-value is a numerical indicator used to measure the degree of risk in an enterprise. $\mathrm{X} 1-\mathrm{X} 5$ is the five ratios of the five factors mentioned above. The specific risk metrics for the 13 sample companies in Table 7 below are calculated by integrating the ratios in Table 6 . 
Table 2 Numerical Synthesis of Risk Variables Prepared by Sample Companies in the Electronics Industry in 2017

\begin{tabular}{|l|l|l|}
\hline $\begin{array}{l}\text { Company } \\
\text { code }\end{array}$ & Company name & Risk metrics Z \\
\hline 000810 & Skyworth Digital & 1.92 \\
\hline 000823 & Unisplendour Corporation & 2.55 \\
\hline 000938 & Unisplendour Corporation & 2.57 \\
\hline 002036 & Lianchuang Electronics & 1.59 \\
\hline 002032 & Supor & 4.56 \\
\hline 002045 & Guoguang Electric & 1.69 \\
\hline 002055 & Deren Electronics & 0.90 \\
\hline 002050 & Sanhua Intelligent Control & 3.17 \\
\hline 002119 & Kang Qiang Electronics & 1.81 \\
\hline 002199 & East Crystal Electronic & 1.55 \\
\hline 002289 & Yushun Electronics & -1.80 \\
\hline 002339 & IESLab & 2.03 \\
\hline 002451 & Morn Electric & 1.03 \\
\hline
\end{tabular}

The Z-metrics are as follows:

\begin{tabular}{|l|l|}
\hline $\mathrm{Z}$ interval & Meaning of Interval \\
\hline $\mathrm{Z}<1.8$ & The company has serious bankruptcy risk \\
\hline $1.8=<\mathrm{Z}<2.8$ & There is a certain risk of bankruptcy \\
\hline $2.8=<\mathrm{Z}<3.0$ & $\begin{array}{l}\text { The company has risks in certain aspects, which may lead } \\
\text { to bankruptcy if uncontrolled }\end{array}$ \\
\hline $\mathrm{Z}>=3.0$ & $\begin{array}{l}\text { The business is in good condition and the risks are within } \\
\text { the controllable range }\end{array}$ \\
\hline
\end{tabular}

\section{Research Conclusion and Related Countermeasures}

Research Conclusion

From the above analysis, it is known that most of the 13 sample companies are more or less at risk of bankruptcy in all respects. Supor proves its very good operating condition with a $\mathrm{Z}$ value of 4.56 , basically the company may The risks faced and already generated are within the controllable range and will not cause adverse reactions of the company. Yushun Electronics' Z-value data of -1.80 indicates that the company has abnormally serious risks. Except for a small number of companies whose $\mathrm{Z}$-value is less than 1.8, most companies in the sample are above the value of 2.0 , which also reflects the rationality of the $\mathrm{Z}$-value model to some extent.

\section{Related Countermeasures}

The company's strategic goals are implemented as specific budget goals. In the operation of a company, its strategic target decision and judgment often bring the strategic risks. The assessment of strategic risks requires the establishment of a complete assessment mechanism. It is proposed that the strategic objectives be implemented as specific budget objectives, and that qualitative and quantitative integration should be adopted to fully align with the company's development strategic objectives, and based on this, the internal organization of the enterprise must be transformed. The system analyzes the drivers of its strategic risks to establish a set of comprehensive monitoring, reporting, and early-warning monitoring methods for risk control, and to ensure that enterprises have comprehensive control and management of risks arising from strategic decisions.

Establish an internal risk prevention mechanism. The three methods for measuring business risks all have their own characteristics and advantages. They measure the size of investment risks from different aspects and can comprehensively compare the three to arrive at a relatively objective standard for foreign investment in enterprises. 


\section{References}

[1] Wan Xining, Su Qiugen. An Empirical Analysis of Early Warning of Financial Failures in Listed Companies [J]. Finance and Accounting Guide, 2003, (9):46-49.

[2] Ye Hua, Cai Gennv. Re-discussion on the Evaluation of Corporate Financial Risks [J]. East China Economic Management, 2005(2):129-132.

[3] Bai Hua. Financial Function Theory: A Critical Review and Reflection [J]. Financial Science, 2004 (3): 101-104.

[4] Liu Yong. Corporate Hedging Motivation in Incomplete Market [J]. Industrial Enterprise Management, 2004 (5): 103-109.

[5] Yu D, Peng L. When does Inferring Reputation Probability Countervail Temptation in Cooperative Behaviors for the Prisoners' Dilemma Game? [J]. Chaos, Solitons \& Fractals, 2015, 78: $238-244$. 